\title{
PENGARUH MODEL PEMBELAJARAN BERBASIS TEKNOLOGI DAN TEKNIK ASESMEN TERHADAP HASIL BELAJAR TERMODINAMIKA
}

Tineke Makahinda

FMIPA Universitas Negeri Manado

\begin{abstract}
The Purpose of this research is to find out the effect of technology based learning model and assessment technique toward thermodynamic achievement by controlling student's intelligence. This research is an experimental research with factorial $2 \times 2$ design. The samples are taken by using cluster random sampling with total respondence of 80 students. The result of the research, after controlling students intelegence, shows that: (I) the students achievement of thermodynamic taught by the environmental use learning model is higher than that of the animation simulation learning model, (2) the students achievement of thermodynamic by project assessment is higher than the students achievement by portfolio assessment, (3) there is interactional effect between learning model based on technology and assessment technique toward thermodynamic achievement, (4) the students achievement of thermodynamic taught by the environmental use learning model by project assessment is higher than that of the animation simulation learning model by project assessment, and (5) the students achievement of thermodynamic taught by the environmental use learning model by project assessment is higher than that of the students achievement of thermodynamic taught by the environmental use learning model by portfolio assessment. Based on the findings of this study, it will be better if the thermodynamic lecture adopted environmental exploitation learning model with the use of project assessment technique.
\end{abstract}

\section{Keywords}

Learning model based on technology, assessment technique, thermodynamic achievement, student intelligence

\begin{abstract}
ABSTRAK
Tujuan penelitian ini adalah untuk melihat pengaruh model pembelajaran berbasis teknologi dan teknik asesmen terhadap hasil belajar Termodinamika, setelah mengontrol intelegensi mahasiswa. Penelitian ini adalah eksperimen dengan desain faktorial $2 \times 2$. Sampel penelitian ini ditentukan dengan cluster random sampling dengan jumlah responden 80 mahasiswa. Hasil penelitian ini setelah mengontrol inteligensi mahasiswa menunjukkan bahwa: I) hasil belajar Termodinamika mahasiswa yang diajar dengan model pembelajaran pemanfaatan lingkungan lebih tinggi dari hasil belajar Termodinamika yang diajar dengan model pembelajaran animasi simulasi, 2) hasil belajar Termodinamika yang dinilai dengan asesmen proyek lebih tinggi dari hasil belajar yang dinilai dengan asesmen portofolio, 3) terdapat pengaruh interaksi antara model pembelajaran berbasis teknologi dan teknik asesmen terhadap hasil belajar Termodinamika mahasiswa, 4) hasil belajar Termodinamika mahasiswa yang diajar dengan model pembelajaran pemanfaatan lingkungan diberi asesmen proyek lebih tinggi dari hasil belajar Termodinamika mahasiswa yang diajar dengan model pembelajaran animasi simulasi diberi asesmen portofolio, dan 5) hasil belajar Termodinamika mahasiswa yang diajar dengan model pembelajaran pemanfaatan lingkungan diberi asesmen proyek lebih tinggi dari hasil belajar Termodinamika mahasiswa yang diajar dengan model pembelajaran pemanfaatan lingkungan diberi asesmen portofolio.
\end{abstract}

\section{Kata Kunci}

Model pembelajaran berbasis teknologi, teknik asesmen, hasil belajar termodinamika, inteligensi mahasiswa

\section{Pendahuluan}

Menciptakan proses pembelajaran dalam rangka mengoptimalkan hasil belajar peserta didik adalah tugas seorang pendidik/dosen. Salah satu faktor penentu pencapaian hasil belajar adalah kemampuan dosen dalam merancang 
(mendesain), menerapkan bahan ajar, serta menata kegiatan perkuliahan. Seperti yang dikatakan Sudjana (2009) bagi guru profesional yang memandang tugasnya sebagai keahlian khusus yang tidak dimiliki profesi lain, hasil penilaian yang dilakukan justru menjadi batu uji bagi keberhasilan dirinya sebagai pengajar sehingga senantiasa dimanfaatkan untuk perbaikan dan penyempurnaan tugas-tugas profesinya. la selalu tidak puas dengan hasil belajar yang dicapai para peserta didik, sehingga hasil penilaian selalu dikaji untuk mencari usaha dan cara baru dalam tindakan mengajarnya agar diperoleh hasil belajar peserta didik yang lebih baik.

Berbagai pendekatan serta model pembelajaran telah digunakan untuk meningkatkan hasil belajar mahasiswa. Pendekatan/model pembelajaran dimaksudkan disini adalah sebagai suatu pola mengajar yang memberikan proses spesifikasi dan penciptaan situasi lingkungan tertentu yang menyebabkan para mahasiswa berinteraksi sehingga terjadi perubahan khusus pada tingkah laku mereka.

Model pembelajaran berbasis teknologi sangat bermanfaat dalam membangun/menguatkan kompetensi akademik sebagai calon guru Fisika maupun non-guru agar memiliki wawasan yang luas dan mendalam serta pemahaman terintegrasi komprehensif tentang konsep/prinsip Fisika serta penerapannya. Dengan pendekatan ini proses pembelajaran makin efektif karena mahasiswa lebih memahami aplikasi dengan konsep Fisika yang dipelajarinya. Peran aktif mahasiswa dalam proses belajar mengajar harus ditunjang dengan pendekatan dan media yang dapat menunjang keberhasilan belajar dan tujuan yang diharapkan.

Pemilihan mata kuliah Termodinamika sebagai sasaran (objek) penerapan model pembelajaran berbasis teknologi didasarkan pada pertimbangan, di Jurusan Fisika FMIPA UNIMA, proses pembelajaran Termodinamika yang diajarkan selalu penekanannya ke teori, mahasiswa tidak pernah melaksanakan praktikum. Ini diakibatkan karena peralatan laboratorium tidak ada untuk mata kuliah Termodinamika dalam mengungkapkan gejala serta prinsip dan konsep hukum-hukum Termodinamika. Model pembelajaran pemanfaatan lingkungan (produk teknologi) dan animasi simulasi merupakan model/metode pembelajaran yang mampu menunjukkan gejala/konsep fisis. Pemanfaatan lingkungan (produk teknologi) seperti: setrika, dispenser, kulkas, mesin pendingin udara (AC), dII sebagai peralatan rumah tangga yang banyak ditemukan di sekitar lingkungan mahasiswa dan juga di bengkel service (jika rusak) dapat mengungkapkan gejala/konsep fisis hukum-hukum Termodinamika. Seperti yang dikemukakan Poedjiadi (200I) pendayagunaan lingkungan (produk teknologi) merupakan suatu pendekatan/model pembelajaran yang berusaha untuk meningkatkan keterlibatan peserta didik melalui pendayagunaan lingkungan (produk teknologi) sebagai sumber belajar. Model pembelajaran ini berasumsi bahwa kegiatan pembelajaran akan menarik perhatian peserta didik bila apa yang dipelajari diangkat dari lingkungannya.

Penerapan model perkuliahan Termodinamika dengan pemanfaatan lingkungan (produk teknologi) dimaksudkan adalah: untuk memberikan kesempatan kepada mahasiswa agar mengenal lebih nyata manfaat/penerapan konsep termodinamika yang dipelajarinya dengan prinsip kerja mesin-mesin yang ada dilingkungannya. Dalam model perkuliahan dengan model pembelajaran berbasis teknologi mahasiswa dilibatkan dalam tiga tahapan proses pembelajaran, yaitu: pembelajaran di kelas, pembelajaran di laboratorium, dan pembelajaran di luar ruang kuliah (bengkel servis, di PLTP, dll) yang ditunjang dengan paket perkuliahan.

Selain penggunaan model pembelajaran yang tepat, hal yang tak dapat dihindari adalah bagaimana proses belajar yang dialami oleh peserta itu dinilai secara tepat pula, karena walaupun proses pembelajarannya sudah tepat tetapi jika tidak ditunjang dengan teknik asesmen yang tepat dapat mengakibatkan keseluruhan proses pembelajaran tidak maksimal dan akan menghasilkan hasil belajar peserta didik yang tidak maksimal pula. Hal tersebut sejalan dengan yang dikemukakan oleh Mardapi (2008) bahwa upaya meningkatkan kualitas pendidikan dapat ditempuh melalui peningkatan kualitas pembelajaran dan kualitas sistem asesmennya.

Kualitas sistem asesmen dalam suatu proses pembelajaran tidak terlepas dari penggunaan teknik asesmen, karena penggunaan teknik asesmen yang kurang tepat akan sangat 
mempengaruhi peserta didik, baik dari segi motivasi belajar, ataupun minat belajar yang pada akhirnya akan mempengaruhi hasil belajar peserta didik selanjutnya.

Suwandi (2010) mengatakan asesmen proyek dapat digunakan untuk mengetahui pemahaman, kemampuan mengaplikasikan, kemampuan penyelidikan, dan kemampuan menginformasikan peserta didik pada mata kuliah tertentu secara jelas. Dalam asesmen proyek ada 3 hal yang perlu dipertimbangkan, yaitu: (I) kemampuan pengelolaan, (2) relevansi, dan (3) keaslian. Seperti yang dikemukakan oleh Surapranata dan Hatta (2004) asesmen proyek harus dilakukan mulai dari pengumpulan, pengorganisasian, pengevaluasian, hingga penyajian data.

Portofolio merupakan kumpulan atau berkas pilihan yang dapat memberikan informasi bagi suatu asesmen. Karakteristik perubahan portofolio mahasiswa dari waktu ke waktu akan merefleksikan perubahan penting dalam suatu proses kemampuan intelektual mahasiswa. Hal Ini sejalan dengan yang dikemukakan oleh Popham (I995) bahwa portofolio merupakan sekumpulan sistematik tentang pekerjaan seseorang. Dalam pendidikan portofolio mengacu pada kumpulan sistematik mengenai pekerjaan siswa. Sedangkan menurut Genesee dan Upshur (1997) portofolio adalah sekumpulan pekerjaan siswa yang dapat menunjukkan kepada mereka (juga bagi yang lain) atas usaha, kemajuan, dan pencapaian mereka dalam bidang studi tertentu

Faktor-faktor keberhasilan belajar di samping model pembelajaran dan teknik asesmen, ada faktor lain yang turut menentukan keberhasilan belajar dari peserta didik, yaitu: inteligensi. Inteligensi merupakan suatu kemampuan mental yang melibatkan proses berpikir secara rasional dari peserta didik atau dengan kata lain inteligensi merupakan kapasitas atau kecakapan dari peserta didik untuk dapat menyesuaikan pikirannya pada situasi/keadaan yang dihadapi peserta didik.

Penelitian ini bertujuan untuk mengetahui pengaruh model pembelajaran berbasis teknologi dan teknik asesmen terhadap hasil belajar Termodinamika setelah mengontrol inteligensi mahasiswa, serta pengaruh interaksi keduanya terhadap hasil belajar Termodinamika mahasiswa semester III Jurusan Fisika FMIPA UNIMA.

\section{Metode Penelitian}

Metode yang digunakan dalam penelitian ini adalah metode eksperimen dengan rancangan faktorial $2 \times 2$. Variabel terikat adalah hasil belajar Termodinamika mahasiswa. Variabel perlakuan adalah: (I) model pembelajaran pemanfaatan lingkungan dan model pembelajaran animasi simulasi, (2) teknik asesmen, yaitu: teknik asesmen proyek dan teknik asesmen portofolio, dan (3) inteligensi mahasiswa sebagai kovariabel.

Tabel I. Desain Penelitian

\begin{tabular}{|c|c|c|}
\hline \multirow[b]{2}{*}{ Teknik Asesmen } & \multicolumn{2}{|c|}{ Model Pembelajaran (A) } \\
\hline & $\begin{array}{c}\text { Pemanfaatan Lingkungan } \\
\text { (Produk Teknologi) }\left(\mathbf{A}_{1}\right)\end{array}$ & Animasi Simulasi $\left(\mathbf{A}_{2}\right)$ \\
\hline \multirow{2}{*}{$\begin{array}{c}\text { Asesmen Proyek } \\
\left(\mathrm{B}_{\mathrm{l}}\right)\end{array}$} & $(\mathrm{X}, \mathrm{Y})_{\| 1 \mathrm{k}}$ & $(X, Y) 21 k$ \\
\hline & $\begin{aligned} k= & 1,2 \ldots n_{11} \\
& \left(A_{1} B_{1}\right)\end{aligned}$ & $\begin{aligned} k= & 1,2 \ldots n_{21} \\
& \left(A_{2} B_{1}\right)\end{aligned}$ \\
\hline \multirow{2}{*}{$\begin{array}{l}\text { Asesmen Portofolio } \\
\qquad\left(B_{2}\right)\end{array}$} & $(X, Y)_{12 k}$ & $(X, Y)_{22 k}$ \\
\hline & $\begin{array}{c}\mathrm{k}=1,2 . . \mathrm{n}_{12} \\
\left(\mathrm{~A}_{1} \mathrm{~B}_{2}\right)\end{array}$ & $\begin{array}{c}k=1,2 \ldots n_{22} \\
\left(A_{2} B_{2}\right)\end{array}$ \\
\hline
\end{tabular}

Populasi terjangkau dalam penelitian ini adalah mahasiswa Fisika FMIPA UNIMA tahun akademik 20II/20I2. Populasi target dalam penelitian ini adalah mahasiswa semester III pendidikan Fisika FMIPA UNIMA jumlah 4 kelas. Sampel penelitian berjumlah 107 mahasiswa. Pengambilan sampel dilakukan dengan cara cluster random sampling.

Instrumen hasil belajar termodinamika sebelum digunakan divalidasi melalui panelis yang terdiri dari 17 butir soal uraian yang dibuat, yang direkomendasikan 15 butir soal berdasarkan 
perhitungan indeks validitas Aiken dan diperoleh koefisien reliabilitas (Hyot) sebesar 0,92. Kemudian diuji-cobakan pada 20 mahasiswa yang bukan kelas perlakuan diperoleh koefisien reliabilitas (alpha Cronbach) sebesar 0,95.

Pengukuran inteligensi mahasiswa dalam penelitian ini dilakukan oleh Jurusan Psikologi UNIMA dengan alat tes CIFT (Culture Fair Intelligence Test) skala 3A dan B dengan izin no. I44/BKIN/PP/2006.

Teknik analisis data dalam penelitian ini terdiri atas: analisis deskriptif, analisis uji prasyarat (meliputi: uji normalitas, uji homogenitas, uji linearitas, uji keberartian, dan uji kesejajaran garis), analisis inferensial untuk uji hipotesis adalah analisis kovarian (ANKOVA).

\section{Hasil Penelitian dan Pembahasan}

Pengujian hipotesis penelitian menggunakan teknik analisis kovarian (ANKOVA). SPSS 19.0 dengan taraf signifikan 0,05 dan hasilnya dapat dilihat pada Tabel 2.

Tabel 2. Rangkuman Hasil ANKOVA

\begin{tabular}{|c|c|c|c|c|c|}
\hline Standar Deviasi & JK & Db & RJK & $\mathbf{F}_{\text {hit }}$ & $\begin{array}{l}\mathbf{F}_{\text {tabel }} \\
\alpha=0,05\end{array}$ \\
\hline Model Dikoreksi & 13867,090 & 4 & 3466,773 & 175,153 & \\
\hline Intercept & 813,505 & I & 813,505 & $4 I, 101$ & \\
\hline$A$ & 1013,773 & I & 1013,733 & 51,217 & \\
\hline B & 416,155 & I & 416,155 & 21,026 & \\
\hline$a * b$ & $5 \mid 4,838$ & I & $5 \mid 4,838$ & 26,011 & 3,96 \\
\hline$x$ & III22,540 & I & III I22,540 & 561,949 & \\
\hline Kesalahan & 1484,460 & 75 & 19,793 & & \\
\hline Total & $1|354| 6,000$ & 80 & & & \\
\hline Total Dikoreksi & $1535 \mid, 550$ & 79 & & & \\
\hline
\end{tabular}

Hasil analisis pengujian hipotesis, pada tabel 2. Pada baris $A$ nilai $F_{\text {hitung }}=51,217$ lebih besar $F_{\text {tabel }}=$ 3,96. dengan demikian $\mathrm{H}_{0}$ ditolak. Berarti terdapat perbedaan hasil belajar Termodinamika antara kelompok mahasiswa yang diajar dengan model pembelajaran pemanfaatan lingkungan dengan kelompok mahasiswa yang diajar dengan model pembelajaran animasi simulasi, setelah mengontrol inteligensi mahasiswa. Pada kelompok mahasiswa yang diajar dengan model pembelajaran pemanfaatan lingkungan, rata-rata hasil belajar Termodinamika dikoreksi adalah I2I,89 sedangkan pada kelompok mahasiswa yang diajar model pembelajaran animasi simulasi hasil belajar Termodinamika dikoreksi adalah: I 14,762. Hasil perhitungan rata-rata dikoreksi menunjukkan bahwa hasil belajar Termodinamika kelompok mahasiswa yang diajar model pembelajaran pemanfaatan lingkungan lebih tinggi dari hasil belajar Termodinamika kelompok mahasiswa yang diajar dengan model pembelajaran animasi simulasi, setelah mengontrol inteligensi mahasiswa.

Hasil analisis pengujian hipotesis, pada tabel 2. Pada baris $B$ nilai $F_{\text {hitung }}=21,026$ lebih besar $\mathrm{F}_{\text {tabel }}=3,96$ dengan demikian $\mathrm{H}_{0}$ ditolak. Berarti terdapat perbedaan hasil belajar Termodinamika antara kelompok mahasiswa yang diberi teknik asesmen proyek dan kelompok mahasiswa yang diberi teknik asesmen portofolio, setelah mengontrol inteligensi mahasiswa. Pada kelompok mahasiswa yang diberi teknik asesmen proyek, rata-rata hasil belajar Termodinamika dikoreksi adalah 120,6I sedangkan pada kelompok mahasiswa yang diberi teknik asesmen portofolio hasil belajar Termodinamika dikoreksi adalah: 116,039. Hasil perhitungan rata-rata dikoreksi menunjukkan bahwa hasil belajar Termodinamika kelompok mahasiswa yang diberi teknik asesmen proyek lebih tinggi dari hasi belajar Termodinamika kelompok mahasiswa yang diberi 
teknik asesmen portofolio, setelah mengontrol inteligensi mahasiswa.

Hasil analisis pengujian hipotesis, pada Tabel 2. Pada baris $A * B$ nilai $\mathrm{F}_{\text {hitung }}=26,0 \mathrm{II}$ lebih besar $\mathrm{F}_{\text {tabel }}=3,96$ dengan demikian $\mathrm{H}_{0}$ ditolak. Berarti terdapat pengaruh interaksi antara model pembelajaran berbasis teknologi (A) dan teknik asesmen (B) terhadap hasil belajar Termodinamika kelompok mahasiswa, setelah mengontrol inteligensi mahasiswa.

Hasil analisis pengujian hipotesis, pada $A_{1} B_{1}$ dan $A_{2} B_{1}$ nilai $t_{\text {hitung }}=8,68$ lebih besar $t_{\text {tabel }(0,05 ; 38)}=$ I,68 dengan demikian $\mathrm{H}_{0}$ ditolak, sehingga dapat disimpulkan: terdapat perbedaan hasil belajar Termodinamika antara kelompok mahasiswa yang diajar model pembelajaran pemanfaatan lingkungan diberi teknik asesmen proyek dan kelompok mahasiswa yang diajar dengan model pembelajaran animasi simulasi diberi teknik asesmen proyek, setelah mengontrol inteligensi mahasiswa. Pada kelompok mahasiswa yang diajar model pembelajaran pemanfaatan lingkungan diberi teknik asesmen proyek $\left(A_{1} B_{1}\right)$, rata-rata hasil belajar Termodinamika dikoreksi adalah I26,72 sedangkan pada kelompok mahasiswa yang diajar model pembelajaran animasi simulasi diberi teknik asesmen proyek $\left(A_{2} B_{1}\right)$ hasil belajar Termodinamika dikoreksi adalah: II5,4I. Hasil perhitungan rata-rata dikoreksi menunjukkan bahwa hasil belajar Termodinamika kelompok mahasiswa yang diajar model pembelajaran pemanfaatan lingkungan diberi teknik asesmen proyek lebih tinggi dari hasil belajar Termodinamika kelompok mahasiswa yang diajar model pembelajaran animasi simulasi diberi teknik asesmen proyek, setelah mengontrol inteligensi mahasiswa.

Hasil analisis pengujian hipotesis, pada $A_{1} B_{2}$ $\operatorname{dan} \mathrm{A}_{2} \mathrm{~B}_{2}$ nilai $t_{\text {hitung }}=1,44$ lebih kecil $t_{\text {tabel }(0,05 ; 38)}=$ I,68 dengan demikian $\mathrm{H}_{0}$ diterima sehingga dapat disimpulkan bahwa tidak terdapat perbedaan hasil belajar Termodinamika antara kelompok mahasiswa yang diajar dengan model pembelajaran pemanfaatan lingkungan diberi teknik asesmen portofolio dan kelompok mahasiswa yang diajar dengan model pembelajaran animasi simulasi diberi teknik asesmen portofolio, setelah mengontrol inteligensi mahasiswa.
Hasil analisis pengujian hipotesis, pada $A_{1} B_{1}$ dan $A_{2} B_{1}$ nilai $t_{\text {hitung }}$ sebesar 6,86 lebih besar $t_{\text {tabel }(0,05 ; 38)}=1,68$ dengan demikian $H_{0}$ ditolak sehingga dapat disimpulkan bahwa terdapat perbedaan hasil belajar Termodinamika antara kelompok mahasiswa yang diajar dengan model pembelajaran pemanfaatan lingkungan diberi teknik asesmen proyek dan kelompok mahasiswa yang diajar dengan model pembelajaran pemanfaatan lingkungan diberi teknik asesmen portofolio, setelah mengontrol inteligensi mahasiswa. Pada kelompok mahasiswa yang diajar model pembelajaran pemanfaatan lingkungan diberi teknik asesmen proyek $\left(A_{1} B_{1}\right)$, rata-rata hasil belajar Termodinamika dikoreksi adalah 1 26,72 sedangkan pada kelompok mahasiswa yang diajar model pembelajaran pemanfaatan lingkungan diberi teknik asesmen portofolio $\left(A_{1} B_{2}\right)$ hasil belajar Termodinamika dikoreksi adalah: 117,06. Hasil perhitungan rata-rata dikoreksi menunjukkan bahwa hasil belajar Termodinamika kelompok mahasiswa yang diajar model pembelajaran pemanfaatan lingkungan diberi teknik asesmen proyek lebih tinggi dari hasil belajar Termodinamika kelompok mahasiswa yang diajar model pembelajaran pemanfaatan lingkungan diberi teknik asesmen portofolio, setelah mengontrol inteligensi mahasiswa.

Hasil analisis pengujian hipotesis, pada $A_{2} B_{1}$ dan $A_{2} B_{2}$ nilai $t_{\text {hitung }}=-0,372$ lebih kecil $t_{\text {tabel }(0,05 ; 38)}$ $=1,68$ dengan demikian $\mathrm{H}_{0}$ diterima sehingga dapat disimpulkan bahwa tidak terdapat perbedaan rata-rata hasil belajar Termodinamika antara kelompok mahasiswa yang diajar dengan model pembelajaran animasi simulasi diberi teknik asesmen proyek dan kelompok mahasiswa yang diajar dengan model pembelajaran animasi simulasi diberi teknik asesmen portofolio, setelah mengontrol inteligensi mahasiswa.

Hasil analisis hipotesis pertama menunjukkan bahwa hasil belajar Termodinamika antara kelompok mahasiswa yang diajar dengan model pembelajaran pemanfaatan lingkungan lebih tinggi dari hasil belajar Termodinamika kelompok mahasiswa yang diajarkan dengan model pembelajaran animasi simulasi, setelah mengontrol inteligensi mahasiswa. Pada perkuliahan Termodinamika model pembelajaran pemanfaatan lingkungan sangat membantu mahasiswa dalam memahami konsep serta prinsip 
fisis. Kegiatan perkuliahan dengan pemanfaatan lingkungan selain dapat berperan sebagai media belajar dapat juga berperan sebagai objek kajian. Beberapa benda di lingkungan kita dapat dimanfaatkan sebagai sumber belajar, baik yang dimanfaatkan secara langsung ataupun yang dirancang terlebih dahulu. Pemanfaatan dilakukan untuk menunjang proses pembelajaran.

Darmadi (2009) mengemukakan bahwa belajar dengan pendekatan lingkungan berarti peserta didik mendapatkan pemahaman dan kompetensi dengan cara mengamati dan melakukan secara langsung apa-apa yang ada dan berlangsung di lingkungan sekitar, baik rumah maupun sekolah. Dalam pada itu, peserta didik dapat menanyakan sesuatu yang ingin diketahui pada orang lain di lingkungan mereka yang dianggap kompeten tentang masalah yang dihadapi.

Berbeda dengan pembelajaran animasi simulasi, pada model pembelajaran ini dosen lebih dominan dalam menginformasikan materi pelajaran dengan menggunakan media visual dalam menunjukkan konsep serta prinsip fisis. Proses pembelajaran dengan model pembelajaran animasi simulasi dapat diartikan cara penyajian pengalaman belajar dengan menggunakan situasi tiruan untuk memahami tentang konsep, prinsip, atau keterampilan tertentu. Model pembelajaran simulasi animasi merupakan model pembelajaran yang membuat suatu peniruan terhadap sesuatu yang nyata, terhadap keadaan sekelilingnya atau proses. Simulasi yang diberikan diusahakan semirip mungkin dengan keadaan yang sebenarnya. Asra (2012) mengemukakan bahwa simulasi dalam pembelajaran berbasis komputer pada dasarnya merupakan salah satu strategi pembelajaran yang bertujuan memberikan pengalaman belajar yang lebih kongkrit melalui penciptaan tiruan-tiruan bentuk pengalaman yang mendekati suasana sebenarnya.

Model pembelajaran ini dirancang untuk membantu peserta didik mengalami bermacammacam proses dan kenyataan sosial untuk menguji reaksi mereka, serta untuk memperoleh konsep keterampilan pembuatan keputusan. Program simulasi berupaya melibatkan peserta didik dalam persoalan yang mirip dengan situasi yang sebenarnya, namun tanpa resiko yang nyata. Model pembelajaran ini dirancang guna menjelaskan suatu keadaan atau materi yang sulit dijangkau secara ril oleh peserta didik.

Dari penjelasan di atas dapat ditarik kesimpulan bahwa pembelajaran dengan pemanfaatan lingkungan adalah pembelajaran nyata yang dapat melibatkan mahasiswa dalam mengalami, yaitu: pengamatan langsung; sedangkan pembelajaran dengan animasi simulasi merupakan pembelajaran abstrak yang membuat suatu peniruan terhadap sesuatu yang nyata, terhadap keadaan sekelilingnya atau proses.

Hasil analisis hipotesis kedua menunjukkan bahwa hasil belajar Termodinamika kelompok mahasiswa yang diberi teknik asesmen proyek lebih tinggi dari hasil belajar Termodinamika kelompok mahasiswa yang diberi teknik asesmen portofolio, setelah mengontrol inteligensi mahasiswa.

Asesmen proyek sebagai salah satu asesmen kelas, yang memiliki prosedur ilmiah yang intinya adalah pengamatan, pengumpulan informasi atau data dari apa yang diamati, menganalisis data, dan menyimpulkan. Tahapan-tahapan tersebut sangatlah relevan dengan prosedur dalam memahami konsep-konsep Termodinamika, sehingga akan sangat membantu proses penemuan atau pengkonstruksian pengetahuan dan pemahaman terhadap konsep-konsep tersebut.

Seperti yang dikemukakan oleh Bastari dan Witjaksono (2008) bahwa proyek adalah tugas yang harus diselesaikan dalam periode/waktu tertentu. Tugas tersebut berupa suatu penelitian sejak dari pengumpulan, pengorganisasian, pengevaluasian, penyajian data, hingga pelaporan.

Mondolang (20I2), melaksanakan penelitian eksperimen dengan judul, "Pengaruh model pembelajaran kooperatif dan teknik penilaian terhadap hasil belajar Fisika dengan mengontrol pengetahuan awal".. Penelitian ini menyimpulkan bahwa ada pengaruh hasil belajar Fisika yang diajar dengan metode kooperatif dengan teknik penilaian proyek setelah mengontrol kemampuan awal.

Asesmen proyek membantu peserta didik mengaplikasikan pengetahuannya berupa konsepkonsep Termodinamika dalam memecahkan masalah atau persoalan-persoalan Termodinamika Proses penemuan dan pengaplikasian konsepkonsep Termodinamika dapat ditempuh melalui pengamatan terhadap gejala-gejala atau fenomena- 
fenomena yang terjadi dalam kehidupan seharihari. Karena konsep dan prinsip fisis pada Termodinamika itu ada di lingkungan mahasiswa maka dengan asesmen proyek sangat membantu dalam pengkonstruksian atau pembentukan pemahaman konsep-konsep Termodinamika.

Sebaliknya untuk asesmen portofolio seperti yang dikemukakan Fajar (2005) asesmen ini sebagai kumpulan pekerjaan mahasiswa dengan maksud tertentu dan terpadu yang diseleksi menurut panduan yang ditetapkan. Asesmen ini kurang mengaktifkan mahasiswa dari segi penemuan sehingga kurang melibatkan aktifitas pengamatan terhadap gejala atau fenomenafenomena yang berada disekitar kehidupan seharihari. Hal ini diperjelas oleh Sanjaya (2007) bahwa portofolio sebagai kumpulan karya siswa yang disusun secara sistematis dan terorganisir sebagai hasil dari usaha pembelajaran yang telah dilakukannya dalam kurun waktu tertentu. Dari beberapa pendapat di atas asesmen portofolio merupakan kumpulan pekerjaan mahasiswa untuk mendapatkan gambaran tentang kemampuan mahasiswa mengemukakan pendapat dalam membuat tugas.

Dari hasil penelitian diperoleh hasil bahwa perkuliahan Termodinamika lebih baik dengan teknik asesmen proyek, karena dengan asesmen ini mahasiswa dilatih membuat laporan ilmiah dan diseminarkan. Sedangkan asesmen portofolio merupakan proses asesmen yang didasarkan pada kumpulan informasi yang menunjukkan perkembangan kemampuan serta unjuk kerja peserta didik dalam satu periode tertentu.

Hasil analisis hipotesis 3 menunjukkan terdapat pengaruh interaksi antara model pembelajaran berbasis teknologi dan teknik asesmen terhadap hasil belajar Termodinamika kelompok mahasiswa, setelah mengontrol inteligensi mahasiswa. Hal ini menunjukkan bahwa antara model pembelajaran dan teknik asesmen sangat berpengaruh satu sama lain dan tidak dapat dipisahkan dalam proses pembelajaran. Ini berarti dalam memilih model pembelajaran harus disesuaikan dengan teknik asesmen yang tepat dengan melihat karakteristik yang akan diajarkan. $\mathrm{Hal}$ ini sejalan dengan pendapat dari Daryanto (2007) bahwa untuk mengukur/menilai suatu proses belajar dilakukan melalui evaluasi dalam pendidikan melalui asesmen/penilaian terhadap perkembangan peserta didik melalui pencapaian tujuan yang ditetapkan. Hasil asesmen dan evaluasi ini merupakan umpan balik untuk mengetahui sampai di mana proses belajar mengajar yang telah dilaksanakan.

Hasil analisis hipotesis 4 menunjukkan bahwa hasil belajar Termodinamika kelompok mahasiswa yang diajar model pembelajaran pemanfaatan lingkungan diberi teknik asesmen proyek lebih tinggi dari hasil belajar Termodinamika kelompok mahasiswa yang diajar model pembelajaran animasi simulasi diberi teknik asesmen proyek, setelah mengontrol inteligensi mahasiswa.

Pembelajaran Termodinamika memiliki karakteristik materi yang memuat tentang gejalagejala atau fenomena-fenomena yang sangat berhubungan dengan peristiwa yang berkaitan dengan lingkungan. Oleh sebab itu dalam proses mengajar dipilih model pembelajaran serta teknik asesmen yang sesuai dengan karakteristik materi dan karakteristik peserta didik. Perpaduan model pembelajaran pemanfaatan lingkungan dengan teknik asesmen proyek sangat berpengaruh terhadap hasil belajar mahasiswa dalam pembelajaran Termodinamika.

Pembelajaran pemanfaatan lingkungan memperkaya wawasan dan pegetahuan peserta didik karena lingkungan merupakan sumber belajar yang dapat digunakan sebagai laboratorium alam yang dapat menunjukkan konsep serta prinsip fisis Termodinamika, sedangkan teknik asesmen proyek sangat sesuai di mana mahasiswa dilatih untuk berpikir ilmiah dalam melaksanakan tugas-tugas dalam bentuk proyek, serta pembentukan keterampilan-keterampilan dalam diri mahasiswa tentang pengetahuan, sikap, dan keterampilan.

Madjid (20II) Karakteristik penting dari asesmen proyek adalah peserta didik dapat menerapkan berbagai keterampilan teori dan praktik yang dimilikinya. Asesmen proyek sangat sesuai dengan tujuan pembentukan sikap dan keterampilan peserta didik karena dalam melaksanakan tugas-tugas dalam bentuk proyek, peserta didik dilatih untuk mempraktekkan sikapsikap ilmiah serta pembentukan keterampilanketerampilan dalam diri siswa dalam merencanakan, menyelidiki, dan menganalisa. Oleh karena itu model pembelajaran pemanfaatan lingkungan sangat cocok dengan teknik asesmen 
proyek, sebab mengikuti langkah langkah ilmiah dalam pelaporan, pengaruhnya terhadap hasil belajar Termodinamika lebih tinggi dibanding dengan model pembelajaran animasi simulasi dengan teknik asesmen proyek.

Hasil analisis hipotesis 5 menunjukkan tidak terdapat perbedaan hasil belajar Termodinamika kelompok mahasiswa yang diajar model pembelajaran pemanfaatan lingkungan diberi teknik asesmen portofolio dan hasil belajar Termodinamika kelompok mahasiswa yang diajar model pembelajaran animasi simulasi diberi teknik asesmen portofolio, setelah mengontrol inteligensi mahasiswa. Hipotesis 5 tidak terbukti dari hasil analisis di atas, sebab proses pembelajaran pemanfaatan lingkungan sangat efektif dilaksanakan dalam perkuliahan Termodinamika, di mana mahasiswa terlibat langsung dalam pengamatan. Model pembelajaran pemanfaatan lingkungan produk teknologi merupakan model yang mengaitkan antara materi yang diajarkan dengan situasi dunia nyata mahasiswa dan mendorong mahasiswa untuk membuat hubungan antara pengetahuan yang dimilikinya dengan penerapan dalam kehidupan sehari-hari. Artinya materi atau konsep yang telah dipelajari tidak mudah dilupakan dan apa yang dipelajari dinilai bermanfaat, seseorang akan termotivasi untuk mempelajari lebih lanjut dalam memperoleh pengetahuan sehingga belajar merupakan kegiatan yang menyenangkan dan menantang.

Setiap kegiatan pembelajaran selalu diukur dengan asesmen. Apakah mahasiswa mampu membuat setiap tugas yang diberikan pada setiap akhir proses pembelajaran. Hal ini seperti yang dikemukakan oleh Arifin (2009), bahwa portofolio proses menunjukkan kegiatan pembelajaran untuk mencapai standar proses, kompetensi dasar, dan sekumpulan indikator yang dituntut oleh kurikulum, dikomentari oleh guru dalam periode tertentu.

Dari kedua model pembelajaran di atas lebih unggul adalah model pembelajaran pemanfaatan lingkungan dibanding dengan model pembelajaran animasi simulasi, di mana model pembelajaran pemanfaatan lingkungan, mahasiswa belajar dengan real (nyata), sedangkan animasi simulasi abstrak yang dibuat real.
Hasil analisis hipotesis 6 menunjukkan bahwa hasil belajar Termodinamika kelompok mahasiswa yang diajar dengan model pembelajaran pemanfaatan lingkungan diberi teknik asesmen proyek lebih tinggi dari hasil belajar Termodinamika kelompok mahasiswa yang diajar dengan model pembelajaran pemanfaatan lingkungan diberi teknik asesmen portofolio. Pembelajaran dengan pemanfaatan lingkungan adalah pembelajaran nyata yang dapat melibatkan mahasiswa dalam mengalami, yaitu: pengamatan langsung.

Menurut Rustaman (1996) banyak keuntungan yang akan diperoleh jika menggunakan lingkungan sebagai sumber belajar yaitu: I) peserta didik mendapatkan informasi berdasarkan pengalaman langsung; karena itu pengajaran akan lebih bermakna dan menarik, 2) pelajaran menjadi lebih konkrit, 3) penerapan ilmu dalam kehidupan sehari-hari menjadi lebih mudah dan sesuai dengan permasalahan yang dihadapi peserta didik, 4) sesuai dengan prinsip-prinsip dalam pendidikan, dan 5) mengembangkan motivasi dan prinsip "belajar bagaimana belajar" berdasar metode ilmiah dan pengembangan keterampilan proses.

Untuk meningkatkan perkuliahan yang efektif serta dapat mengukur ketercapaian tujuan yang diajarkan sebaiknya di samping model pembelajaran pemanfaatan lingkungan juga dapat dipadukan dengan teknik asesmen. Asesmen yang cocok untuk pemanfaatan lingkungan adalah asesmen proyek, di mana asesmen ini memilki prosedur yang dipandang sangat sesuai dengan proses pemahaman konsep serta prinsip fisis Termodinamika yang dibangun dari adanya gejala atau fenomena-fenomena yang teramati dan mahasiswa membuat laporan ilmiah dan dipresentasikan. Hal ini sejalan dengan pendapat Suprijono (20II) bahwa proyek adalah suatu tugas yang melibatkan kegiatan perancangan, pelaksanaan, dan pelaporan secara tertulis maupun lisan dalam waktu tertentu dan umumnya menggunakan data lapangan. Dari pendapat di atas model pembelajaran pemanfaatan lingkungan lebih cocok dipadukan dengan asesmen proyek.

Hasil analisis hipotesis 7 menunjukkan bahwa tidak terdapat perbedaan hasil belajar Termodinamika kelompok mahasiswa yang diajar model pembelajaran animasi simulasi diberi teknik asesmen proyek dan hasil belajar Termodinamika 
kelompok mahasiswa yang diajar model pembelajaran animasi simulasi diberi teknik asesmen portofolio, setelah mengontrol inteligensi mahasiswa. Hipotesis 7 tidak terbukti dari hasil analisis $\mathrm{di}$ atas, sebab proses pembelajaran animasi simulasi diberi teknik asesmen proyek lebih efektif dilaksanakan dalam perkuliahan Termodinamika dari pada animasi simulasi diberi teknik asesmen portofolio, di mana asesmen proyek akan memberikan informasi tentang pemahaman dan pengetahuan peserta didik pada proses pembelajaran tertentu, kemampuan peserta didik dalam mengaplikasikan pengetahuan, dan kemampuan peserta didik untuk mengkomunikasikan informasi.

\section{Kesimpulan}

Hasil temuan dari penelitian ini adalah: hasil belajar Termodinamika kelompok mahasiswa yang diajar model pembelajaran pemanfaatan lingkungan lebih tinggi dari hasil belajar Termodinamika kelompok mahasiswa yang diajar dengan animasi simulasi, setelah mengontrol inteligensi mahasiswa. Hasil belajar Termodinamika kelompok mahasiswa yang diberi teknik asesmen proyek lebih tinggi dari hasil belajar Termodinamika kelompok mahasiswa yang diberi teknik asesmen portofolio, setelah mengontrol inteligensi mahasiswa. Terdapat pengaruh interaksi antara model pembelajaran berbasis teknologi dan teknik asesmen terhadap hasil belajar Termodinamika kelompok mahasiswa, setelah mengontrol inteligensi mahasiswa. Hasil belajar Termodinamika kelompok mahasiswa yang diajar model pembelajaran pemanfaatan lingkungan diberi teknik asesmen proyek $\left(A_{1} B_{1}\right)$ lebih tinggi dari hasil belajar Termodinamika kelompok mahasiswa yang diajar model pembelajaran animasi simulasi diberi teknik asesmen proyek $\left(A_{2} B_{1}\right)$, setelah mengontrol inteligensi mahasiswa. Hasil belajar Termodinamika kelompok mahasiswa yang diajar model pemanfaatan lingkungan diberi teknik asesmen proyek $\left(A_{1} B_{1}\right)$ lebih tinggi dari hasil belajar Termodinamika kelompok mahasiswa yang diajar model pemanfaatan lingkungan diberi teknik asesmen portofolio $\left(A_{1} B_{2}\right)$, setelah mengontrol inteligensi mahasiswa.

\section{Daftar Pustaka}

Arifin, Zainal. (2009). Evaluasi Pembelajaran: Prinsip, Teknik, Prosedur. Bandung: Remaja Rosdakarya.

Asra, Cepi Riyana. Komputer Sebagai Media Pembelajaran. http://edy-wihardjo.blog. unej. ac.id.

Bastari dan Witjaksono. (2008). Penilaian Proyek. Jakarta: Pusat Penilaian Pendidikan, Badan Penelitian dan Pengembangan, Departemen Pendidikan Nasional.

Darmadi, Hamid. (2009). Kemampuan Dasar Mengajar. Bandung: Alfabeta.

Daryanto. (2007). Evaluasi Pendidikan. Jakarta: Rineka Cipta.

Fajar, Arnie. (2005) Portofolio Dalam Pembelajaran. Bandung: Remaja Rosdakarya.

Genesee, Fred dan John A. Upshur. (1997). Classroom-Based Evaluation In Second Language Education. Cambridge: Cambridge University Press.

Mardapi Djemari. (2008). Teknik Penyusunan Instrumen Tes dan Non tes Jakarta: Mitra Cendikia.

Mondolang, Aswin. (2012). Pengaruh Model Pembelajaran Kooperatif dan Teknik Penilaian terhadap Hasil Belajar Fisika dengan Mengontrol Pengetahuan Awal Siswa: Eksperimen di SMPN I dan SMPN 2 Tondano. Disertasi. Jakarta: Universitas Negeri Jakarta.

Poedjiadi, Anna. (2002). Sains Teknologi Masyarakat. Bandung: Remaja Rosdakarya.

Popham, W. James. (1995). Classroom Asesment What Teachers Need to Know. Boston: Allyn and Bacon. 
Rustaman, A. (1996). Pemanfaatan Lingkungan Sebagai Sumber Belajar IPA. Jakarta: Balitbang DIKBUD.

Sanjaya, Wina. (2007). Strategi Pembelajaran Berorientasi Standar Proses Pendidikan. Jakarta: Prenada Media.

Sudjana, Nana. (2009). Penilaian Hasil proses Belajar Mengajar. Bandung: Remaja Rosdakarya.
Suprijono, Agus. (20II). Cooperatif Learning Teori dan Aplikasi PAIKEM. Yogyakarta: Pustaka Pelajar.

Surapranata, Sumarna dan Muhammad Hatta. (2008). Penilaian Portofolio. Jakarta: Departemen Pendidikan Nasional.

Suwandi, Sarwiji. (2010). Model Assessment dalam Pembelajaran. Surakarta: Yuma Pustaka. 